\title{
Colonisation of hard substrata along a channel system in the deep Greenland Sea
}

\author{
Miriam Schulz • Melanie Bergmann • \\ Karen von Juterzenka $\cdot$ Thomas Soltwedel
}

Received: 7 May 2010/Accepted: 10 May 2010/Published online: 30 May 2010

(C) The Author(s) 2010. This article is published with open access at Springerlink.com

\begin{abstract}
The colonisation of hard substrata (HS) by epibenthic megafauna was studied by photographic surveys along the Ardencaple Canyon in the deep western Greenland Sea in 2000. Seven transects at 2,700-3,200 m water depth showed generally low densities of dropstones, sunken wood, and other substrata including anthropogenic material (range: 2-11 $\mathrm{HS} \mathrm{km}^{-1}$ ). Overall, 30 different taxa and morphotypes were found on or associated with HS. While the sea anemone Bathyphellia margaritacea and the pantopod Ascorhynchus abyssi dominated the fauna on the substrate surfaces, a ball-shaped morphotype of uncertain taxonomic origin characterised assemblages marginally associated with HS. Community analysis revealed differences in faunal patterns near the continental rise and towards the deep sea, but diversity and evenness did not differ significantly between the various regions. However, we conclude that dropstones and other hard substrata at the seafloor serve as colonisation islands and thereby generally increase small-scale habitat diversity in polar deep-sea environments.
\end{abstract}

M. Schulz

Baltic Sea Research Institute, Warnemünde, Seestrasse 15, 18119 Warnemünde, Germany

M. Bergmann $(\varangle) \cdot$ T. Soltwedel

Alfred Wegener Institute for Polar and Marine Research, Am Handelshafen 12, 27570 Bremerhaven, Germany

e-mail: Melanie.Bergmann@awi.de

K. von Juterzenka

Institute for Polar Ecology, Wischhofstrasse 1-3,

24148 Kiel, Germany
Keywords Community structure - Channel systems · Epibenthic megafauna - Dropstone · Hard substrata . Ardencaple canyon · Greenland Sea · Arctic

\section{Introduction}

Geological and biogenic structures such as manganese nodules, whale bones, and sponge stalks represent hard substrata (HS) in soft-bottom deep-sea environments (e.g. Mullineaux 1987; Bennett et al. 1994; Beaulieu 2001; Baco and Smith 2003; Felley et al. 2008; Buhl-Mortensen et al. 2010). In Arctic seas, deglaciation at the end of the last ice age and recent seasonal melting processes in marginal ice zones (MIZ) provide a source for ice-rafted dropstones, which might serve as space-limited hard-bottom "islands" in pelagic sediments (Oschmann 1990; MacDonald et al. 2010).

While some epifaunal species are restricted to hard substrata, others show a high plasticity in terms of substrate choice (e.g. Riemann-Zürneck 1997). The dispersion of the HS-associated fauna depends on dispersion and settlement patterns of their larvae, substrata availability and food accessibility (Mullineaux 1988). However, effects of hard substrata on epibenthic community patterns have rarely been considered in attempts to assess species diversity in the deep sea. The lack of knowledge about deep-sea HS-communities, apart from hydrothermal vent and ridge sites, is mainly due to restrictions in sampling by conventional methods like box coring or dredging (Christiansen and Thiel 1992; Beaulieu 2001). Furthermore, because of the low density of megafauna in deep soft-bottom habitats, it is difficult to acquire quantitative information (Bluhm 1994). Seabed imaging techniques such as those used for the description of distribution and community patterns of 
epibenthic megafauna from soft-bottom environments (e.g. Mayer and Piepenburg 1996; Ambrose et al. 2001; Bluhm et al. 2005; Soltwedel et al. 2009), and biogenic "substrate islands" such as sponge stalks (Beaulieu 2001) are valuable tools to quantitatively characterise epibenthic communities on hard substrata (Rice et al. 1982; Solan et al. 2003).

To our knowledge, a description of dropstone colonisation has so far relied on the material obtained by box core sampling in the Norwegian Sea (Oschmann 1990) and a camera survey in the Canada Basin (MacDonald et al. 2010). Both studies reported a high diversity of epibenthic colonisers although Oschmann's (1990) study described only the epifauna of ten dropstones of $\leq 8 \mathrm{~cm}$ diameter.

The aim of the present study was to describe the colonisation of $\mathrm{HS}$ in the Ardencaple Canyon situated at 74$75^{\circ} \mathrm{N}$ and $7-13^{\circ} \mathrm{W}$ off the eastern Greenland coast, and to analyse the observed community patterns in relation to the channel-specific topography. This study complements investigations on distribution patterns of small benthic biota (bacteria to meiofauna; Soltwedel et al. 2005) and mega-epibenthic assemblages in and around the channel system (Juterzenka and Soltwedel, unpubl. data), which were part of the multidisciplinary German project ARKTIEF II.

\section{Materials and methods}

Study area and seafloor photography

Investigations of epibenthic megafauna were conducted in the western Greenland Sea at $74-75^{\circ} \mathrm{N}$ and $10-11^{\circ} \mathrm{W}$ in the Ardencaple Canyon, $\sim 250 \mathrm{~km}$ off the eastern Greenland coast (Fig. 1). Its proximal part is $\sim 2 \mathrm{~km}$ wide, and the channel floor is $\sim 100 \mathrm{~m}$ deeper than the surroundings (Krause and Schauer 2000). In summer, the area is located in the vicinity of the MIZ (Vinje 1977; Ramseier et al. 2001).

Photographs of the seafloor were taken by the towed Ocean Floor Observation System (OFOS) during the expedition ARK XVI/1 of RV Polarstern (July 2000) at $\sim 2,700-3,000 \mathrm{~m}$ water depth. The OFOS was towed along five transects crossing the channel, and two transects along the channel axis (Table 1). The OFOS frame was equipped with a still camera (Benthos), which was triggered manually or at 30-s intervals, allowing for up to 800 shots per track (Kodak Ektachrome 100 ASA slide film). Three laser pointers served as a size reference. The system was towed at $\sim 1.5 \mathrm{~m}$ altitude with a drift velocity of $\sim 0.5$ knots. Voucher-specimens for ground-truthing were collected

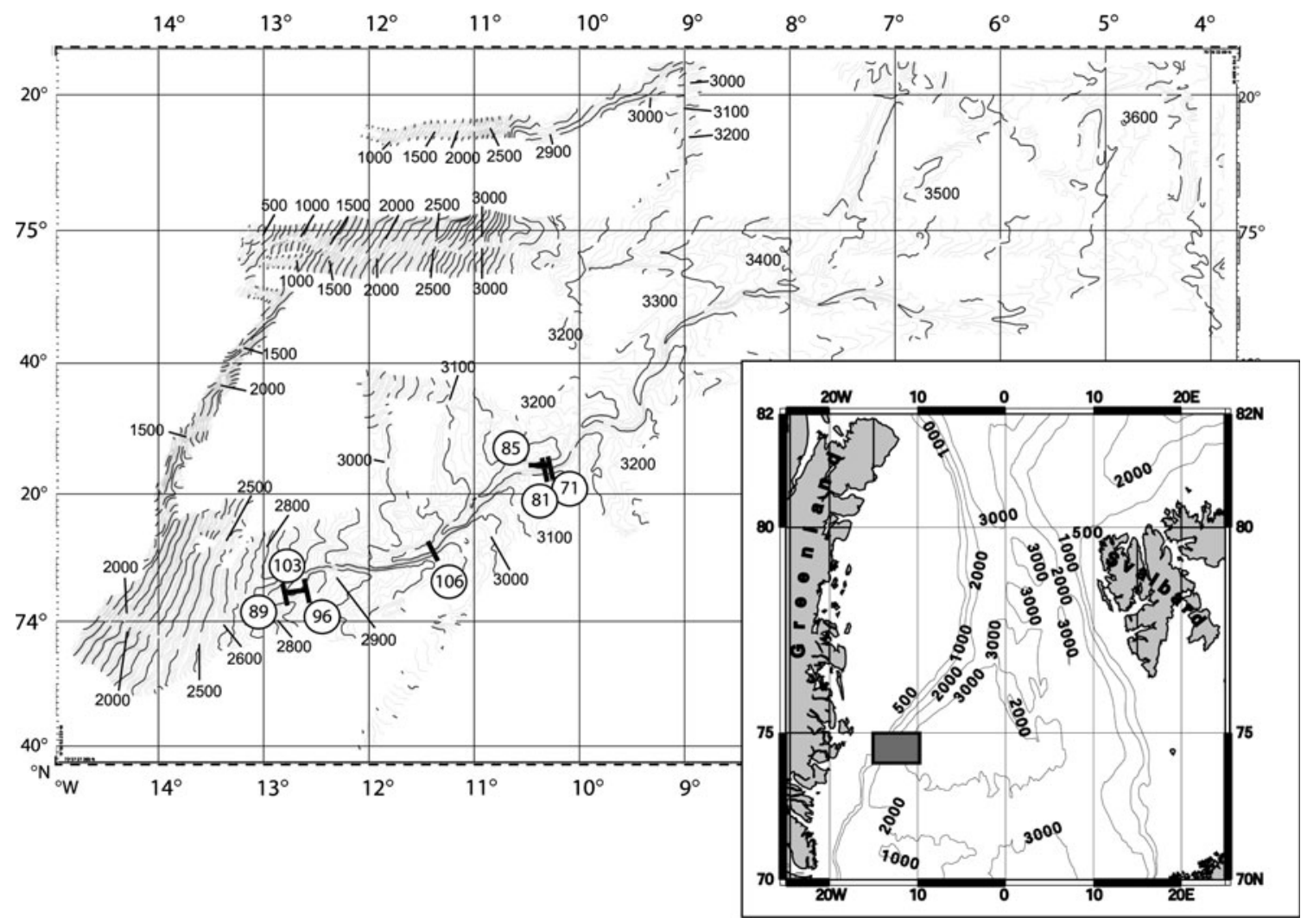

Fig. 1 Study sites in the proximal part of the Ardencaple Canyon east off Greenland; location of the sampling stations (numbers in the circles represent abbreviated station numbers, e.g. $71=$ PS57-71; see also Table 1) 
Table 1 Seafloor photography at the Ardencaple Canyon during expedition ARK XVI/1 in summer 2000

\begin{tabular}{|c|c|c|c|c|c|c|c|}
\hline \multirow[t]{2}{*}{ Station no. } & \multicolumn{2}{|c|}{$\begin{array}{l}\text { Position at the beginning } \\
\text { of the transect }\end{array}$} & \multirow{2}{*}{$\begin{array}{l}\text { Region and orientation } \\
\text { of transects to channel } \\
\text { axis }\end{array}$} & \multirow[t]{2}{*}{$\begin{array}{l}\text { Length of transects } \\
\text { at the seafloor }(\mathrm{m})\end{array}$} & \multirow[t]{2}{*}{$\begin{array}{l}\text { Depth } \\
\text { range }(\mathrm{m})\end{array}$} & \multicolumn{2}{|c|}{$\begin{array}{l}\text { No. of images analysed } \\
\text { and identified HS }\end{array}$} \\
\hline & Latitude (N) & Longitude (W) & & & & $n$ & HS \\
\hline PS57-71 & $74^{\circ} 22.2^{\prime}$ & $10^{\circ} 18.3^{\prime}$ & East, across & 6,170 & $2,960-3,220$ & 73 & 18 (19) \\
\hline PS57-81 & $74^{\circ} 25.2^{\prime}$ & $10^{\circ} 22.0^{\prime}$ & East, across & 5,610 & $3,130-3,210$ & 10 & 12 \\
\hline PS57-85 & $74^{\circ} 24.0^{\prime}$ & $10^{\circ} 29.4^{\prime}$ & East, along & 3,700 & $3,190-3,210$ & 12 & 12 \\
\hline PS57-89 & $74^{\circ} 02.5^{\prime}$ & $12^{\circ} 48.3^{\prime}$ & West, across & 5,600 & $2,760-2,840$ & 75 & 16 \\
\hline PS57-96 & $74^{\circ} 03.4^{\prime}$ & $12^{\circ} 38.1^{\prime}$ & West, across & 5,120 & $2,780-2,880$ & 42 & 47 \\
\hline PS57-103 & $74^{\circ} 05.1^{\prime}$ & $12^{\circ} 40.3^{\prime}$ & West, along & 5,490 & $2,830-2,870$ & 20 & $20(21)$ \\
\hline PS57-106 & $74^{\circ} 11.9^{\prime}$ & $11^{\circ} 28.1^{\prime}$ & Central, across & 5,040 & $2,950-3,080$ & 92 & $51(54)$ \\
\hline
\end{tabular}

In parentheses: number of HS found at the transect

nearby by a small Agassiz trawl in 2002 (for details see Krause and Schauer 2000; Fahrbach 2002).

Image analysis

All slides (155 in total) showing HS $>10 \mathrm{~cm}^{2}$ were analysed for the abundance and composition of epibenthic megafauna, using a stereomicroscope WILD M3B. All biota $\geq 0.5 \mathrm{~cm}$ were counted. The fauna linked to HS was divided into two groups of organisms, (1) specimens observed on the HS surface, and (2) specimens in close vicinity to the HS ("associated" with HS). All organisms linked to HS were identified to the highest taxonomic level possible (using Stephensen 1943, 1944; Gaevskaja 1948; Andersen 1971; Barthel and Tendal 1993; Witte 1995; Riemann-Zürneck 1997; Schuchert 2001). Where necessary, reference material was identified by expert taxonomists (see acknowledgements). Several structures were identified by colour, shape and general habitus (Table 2). However, it was impossible to further classify them because of a lack of recognisable characteristics. Colonies of sponges, bryozoans and other colonial organisms were counted as single individuals.

Because of a varying altitude of the OFOS, the camera footprint ranged from $0.7-3.0 \mathrm{~m}^{2}$. Single large HS did not show all potentially associated fauna on the specific image. Abundances of HS were normalised to a length of $1 \mathrm{~km}$ $\left(\mathrm{HS} \mathrm{km}{ }^{-1}\right)$. HS surfaces were measured using the software "POLY M" ( ${ }^{\odot}$ M. Peters), which enables area calculations on digital images. Abundances per $\mathrm{m}^{2} \mathrm{HS}$, and abundances per $\mathrm{m}^{2}$ seafloor were determined for the fauna observed on and associated with HS, respectively (Table 3). Three subsamples of 18-20 slides (taken at 30-s time intervals) were analysed from transect PS57-89 to determine if the anemone Bathyphellia margaritacea, the pantopod Ascorhynchus abyssi and the ball-shaped Morphotype I occur exclusively on HS or favour soft bottoms. The same
Table 2 Description of taxa and morphotypes

\begin{tabular}{|c|c|}
\hline $\begin{array}{l}\text { Taxa/ } \\
\text { morphotype }\end{array}$ & Description \\
\hline $\begin{array}{l}\text { Encrusting } \\
\text { sponge }\end{array}$ & Bluish, flat sponge, crusty, white \\
\hline Hydrozoa sp. & Capillary branched, thin braches \\
\hline Actinaria? & $\begin{array}{l}\text { Not clearly identified as } B \text {. margaritacea, similar } \\
\text { shape and colour }\end{array}$ \\
\hline Anthozoa sp. & Fan-shaped specimen, blue, triangular \\
\hline cf. Bryozoa & Colonies rather flat, thick branches, white \\
\hline $\begin{array}{l}\text { Polychaeta, } \\
\text { Sedentaria }\end{array}$ & $3-4 \mathrm{~cm}$ tube, diameter of tentacle crown $\sim 2 \mathrm{~cm}$ \\
\hline Amphipoda sp. & White, $\sim 2 \mathrm{~cm}$ length \\
\hline Amphipoda sp.? & Not clearly identified as Amphipoda sp. \\
\hline Stalked crinoid & $\begin{array}{l}\text { Size } \sim 10 \mathrm{~cm}, \text { most probably Bathycrinus } \\
\text { carpenterii }\end{array}$ \\
\hline Asteroida sp. & White, habitus similar to Poranimorpha tumida \\
\hline Morphotype I & Globular organisms, brown, mud ball-like \\
\hline Morphotype II & $\begin{array}{l}\text { Blue, roundly, partly osculae-like structures } \\
\text { visible, probably sponge }\end{array}$ \\
\hline Morphotype III & $\begin{array}{l}\text { Light blue, oval, osculae-like structures visible, } \\
\text { probably sponge }\end{array}$ \\
\hline Morphotype IV & $\begin{array}{l}\text { Brown, flat, osculae-like structures visible, } \\
\text { probably sponge }\end{array}$ \\
\hline Taxon I & Whitish, round, encrusting taxon \\
\hline Taxon II & Blue, elongate (possibly egg masses) \\
\hline Taxon III & $\begin{array}{l}\text { Blue, big, massive specimen, irregular shape, } \\
3-5 \mathrm{~cm}\end{array}$ \\
\hline Taxon IV & Dark-blue, round objects \\
\hline Taxon V & Blue, small, round, rather flat objects \\
\hline Taxon VI & Grey-blue objects, $\varnothing \sim 1 \mathrm{~cm}$ \\
\hline Taxon VII & Dark brown, small, round, flat, associated with HS \\
\hline Taxon VIII & Light brown, globular-shaped object $\varnothing 4-5 \mathrm{~cm}$ \\
\hline Taxon IX & $\begin{array}{l}\text { Eggplant-like shape, whitish, without structure, } \\
\text { possibly holothuroid }\end{array}$ \\
\hline Taxon $\mathrm{X}$ & $\begin{array}{l}\text { Flat, oblong, lightly, about } 5 \mathrm{~cm} \text {, possibly } \\
\text { crustacean }\end{array}$ \\
\hline
\end{tabular}




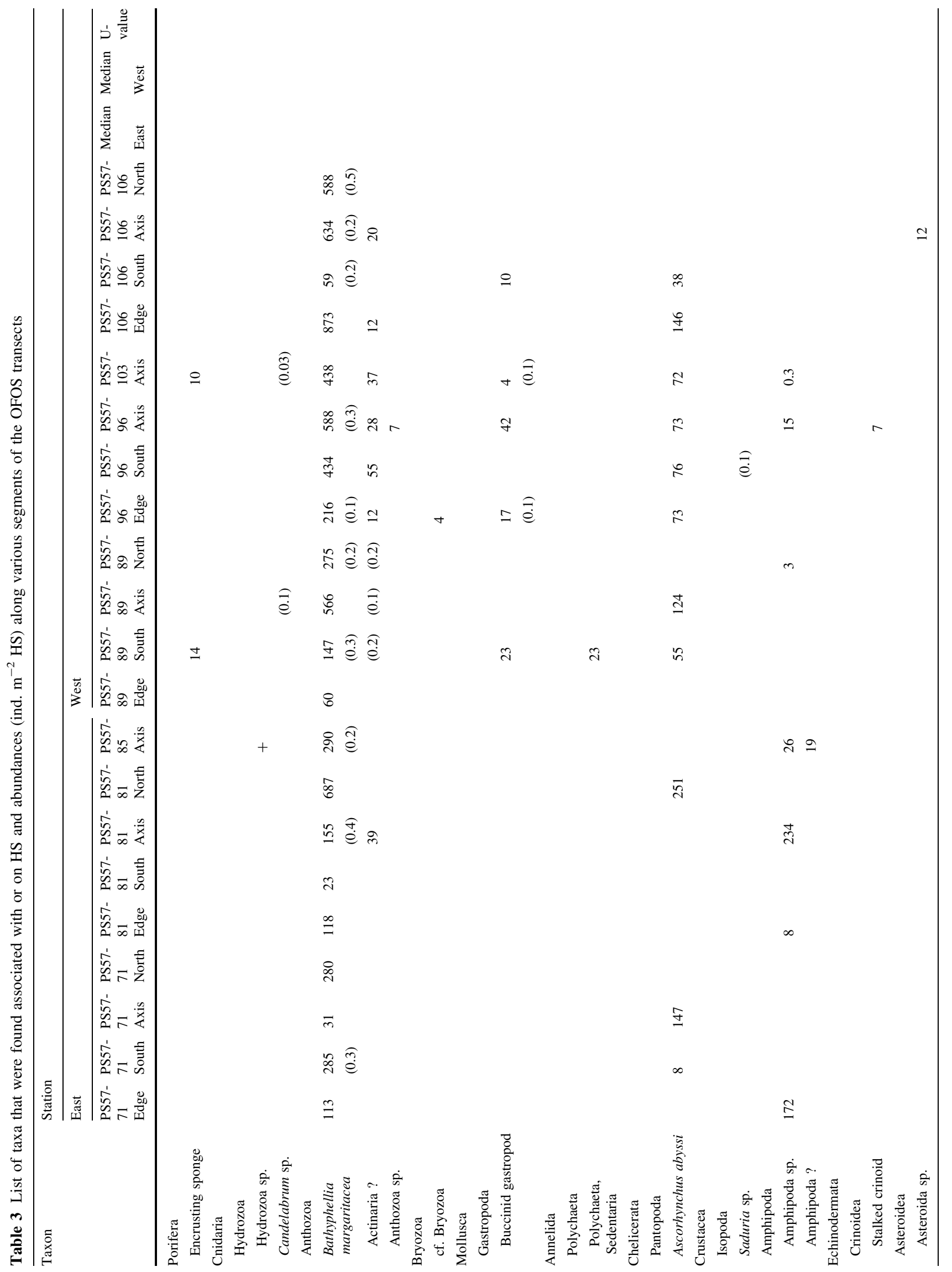




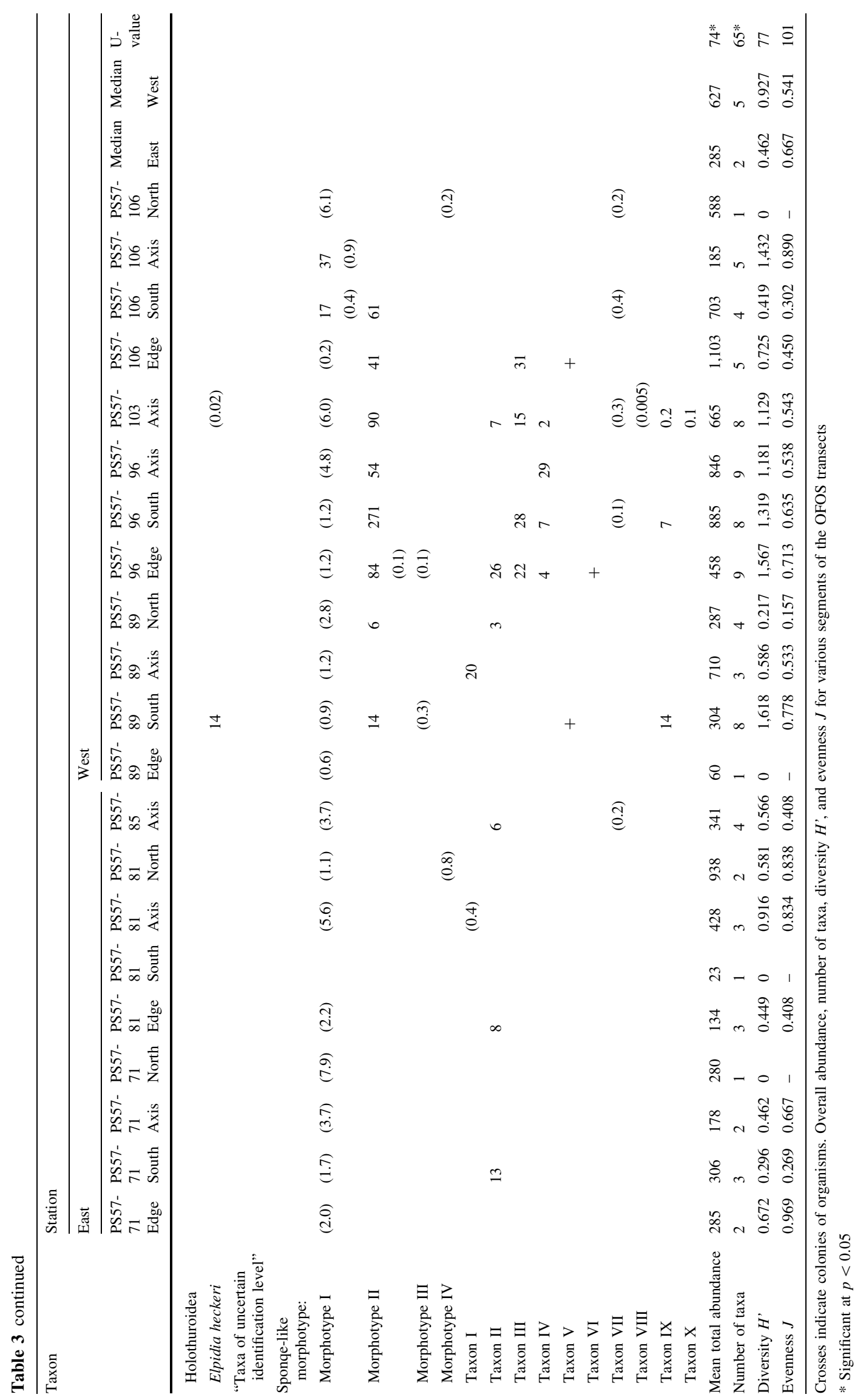


sub-samples were used to estimate densities of the three selected species on HS.

Data analysis

OFOS transects were grouped a priori according to their location along the channel ("West", "Central", and "East") and topographic segments of the OFOS transects ("northern slope", "southern slope", "channel-axis", "channeledge"). Differences in the community patterns between the channel areas and the topographic segments, respectively, were tested by ANOSIM (Clarke and Warwick 1994). The community analysis was based on the mean abundance of 22 taxa on HS at each of the 21 segments from the five transects. Hydrozoa sp., and Taxa V and VI (see Table 2) were excluded from the community analysis because it was impossible to quantify these structures (boundaries of colonies were not always visible). These taxa were rare and never covered large areas of the dropstones.

Using PRIMER V 5.0 (Plymouth Marine Laboratory, UK), a similarity matrix was calculated based on the BrayCurtis coefficient (Bray and Curtis 1957). Square-root transformation of abundances was used to buffer the influence of very abundant taxa (Field et al. 1982). Because of a lack of replicates, results from transect PS57-106 were excluded from the test. Results of the ANOSIM tests were depicted through multi-dimensional scaling (MDS; Kruskal 1977). Total abundance, number of taxa, evenness $J$ (Pielou 1977) and diversity $H^{\prime}$ (log-transformed; Shannon and Weaver 1949) were tested for significant differences between regions by Mann-Whitney U tests. A Spearman rank correlation was used to test the relationship between the number of individuals linked to the HS and the size of the HS. "Discriminator taxa" were identified by the SIMPER routine (Clarke 1993).

\section{Results}

Composition and densities of hard substrata

In total, 155 images showed $181 \mathrm{HS}, 176$ of which could be measured and analysed. Three groups of HS were distinguished (Fig. 2). In addition to dropstones and pieces of wood, a diverse third group, defined as "others", contained anthropogenic debris, pieces of bones, and some indefinable structures. While stones accounted for $>50 \%$ of HS, wooden structures ranged between 6 and 31\%, similar to the third group ("others"). Over the whole study area, dropstones accounted for $81 \%$ of the HS (Fig. 3a).

Normalised densities of $\mathrm{HS}>10 \mathrm{~cm}^{2}$ on transects ranged between 2.1 and $10.8 \mathrm{HS} \mathrm{km}^{-1}$. However, specific segments of the transects showed a higher variability, with
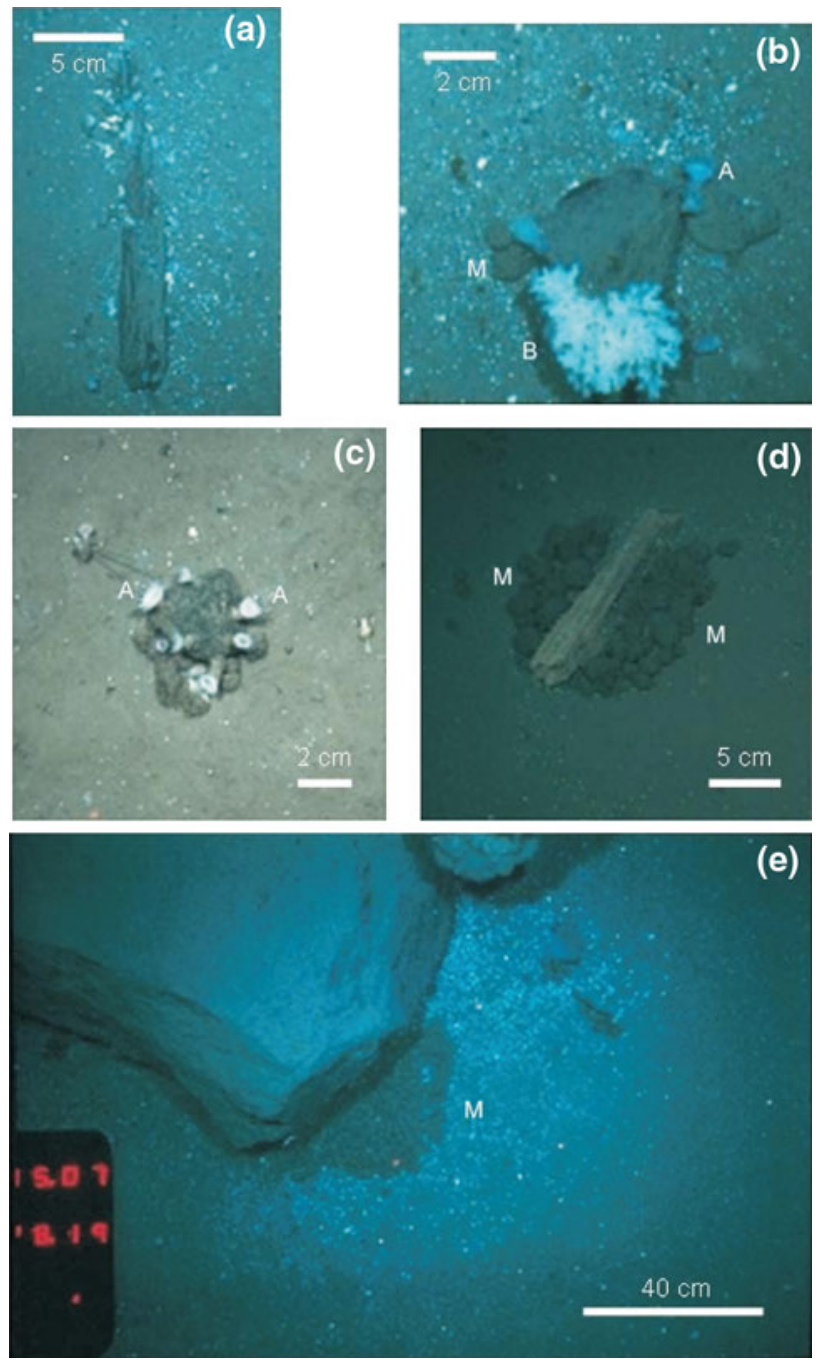

Fig. 2 In situ images of HS-linked fauna in the Ardencaple Canyon and the surrounding deep Greenland Sea: $M$ morphotype I, $B$ Bryozoa sp., A Bathyphellia margaritacea; a rocky substrate, b dropstone, c dropstone colonised by anemones, $\mathbf{d}$ wood and e large stone with associated aggregation of mudball-like morphotype I

a maximum density of $48.2 \mathrm{HS} \mathrm{km}^{-1}$ at the "southern slope" of the transect PS57-106. HS sizes varied between 11 and $7,684 \mathrm{~cm}^{2}$ with $84.7 \%$ of the HS being smaller than $150 \mathrm{~cm}^{2}$. On average, some $25 \%$ of HS were not colonised by megafauna.

Fauna on and associated with hard substrata

Epifaunal abundance on HS varied between 0 and 1,103 individuals $\mathrm{m}^{-2}$ HS. Densely colonised and bare HS were observed in close neighbourhood. Although the coverage of HS was variable, the size of a particular HS correlated with the abundances of the individuals found on and associated with HS, respectively $\left(R_{\mathrm{On}} \quad \mathrm{HS}=0.44\right.$, $p<0.001)$; $\mathrm{R}_{\text {associated with HS }}=0.34, p<0.001$; Fig. 3a, b). Most HS harboured $<15$ individuals (Fig. 3a). 


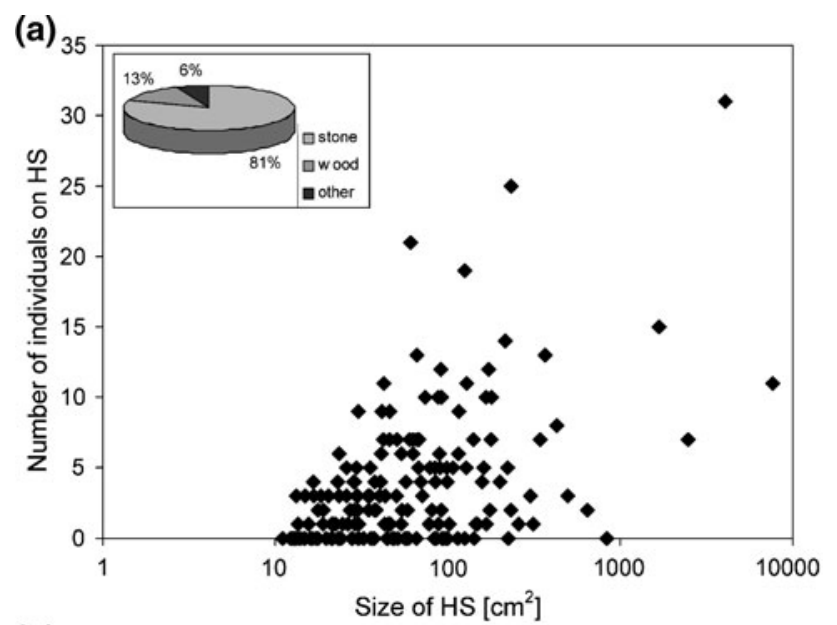

(b)

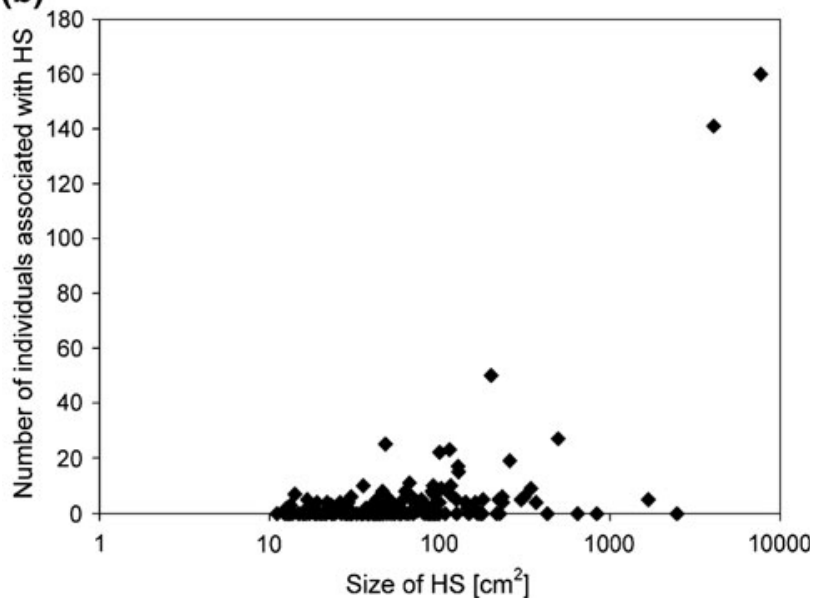

Fig. 3 Abundances of organisms vs. substrate size $>10 \mathrm{~cm}^{2}$ (note: size of substrata is in log scale). a Individuals observed on the surface of HS. The pie chart shows the proportions of the different groups of HS, integrated over the whole study area. b Individuals associated with HS

HS-associated organisms mostly accounted for $<10$ individuals (Fig. 3b).

Only a fraction of the species visible on images was collected by trawl such that only a few taxa could be identified to species or genus level. The ball-shaped morphotypes I-IV very likely included sponges, since they resemble small-sized deep-sea sponges such as Thenea abyssorum in shape, size and colour. Overall, 23 taxa and morphotypes (Table 2) were found on the surface of HS; 13 appeared to be associated with HS. Six of the latter occurred on the surrounding sediment surface as well. Thus, a total of 30 taxa were linked to HS (Table 3).

The small white actinian Bathyphellia margaritacea was abundant in all channel segments (23-873 ind. $\mathrm{m}^{-2}$ ) with highest densities on HS from the centre of the study area (Table 3). At most segments, B. margaritacea accounted for $50 \%$ of the colonisers. We also observed anemones on small stones, shell fragments, snails and sea urchin tests.
Sometimes, no substrate could be recognised underneath the anemone, at all.

The pantopod Ascorhynchus abyssi occurred in lower densities (0-258 ind. $\mathrm{m}^{-2}$ ) and was absent from some segments (Table 3). Generally, it was more abundant in the western part than in the eastern part of the channel.

The ball-shaped Morphotype I constituted the dominant group associated with HS (0-7.9 ind. $\left.\mathrm{m}^{-2}\right)$ and was found at all segments, except for the "southern slope" of transect PS57-81 (Table 3). At five segments, Morphotype I was the only HS-associated taxon.

"Encrusting sponge", Anthozoa sp., Bryozoa cf., Polychaeta sp., Crinoidea sp. (Bathycrinus carpenterii?), Elpidia heckeri as well as Taxa I, IV, VIII, and X on HS were exclusively observed in the western part of the study area (Table 3). Also, 8 out of 13 "associated taxa" were solely found in the west of the channel (Table 3). Morphotype I was more abundant at all "northern slopes" of the channel, compared with other channel segments.

Distribution of dominant taxa on hard substrata versus soft-bottom habitats

The most prominent taxa were investigated with respect to substrate preferences. The anemone $B$. margaritacea occurred in significantly higher densities on HS $(z=19.6$, $p<0.001$; Fig. 4a) than on sediments. Densities ranged from 0.3 to 2.1 ind. $\mathrm{m}^{-2}$ on $\mathrm{HS}$ and did not exceed 1 ind. $\mathrm{m}^{-2}$ on sediments. The pantopod A. abyssi and the ball-shaped Morphotype I (associated fauna) preferred softbottom habitats over hard substrates $(z=1.7, p>0.05$; Fig. $4 \mathrm{~b}$, respectively, $z=2.3, p<0.05$; Fig. $4 \mathrm{c}$ ).

\section{Community structure}

Community patterns were described for fauna from HS. ANOSIM indicated no significant faunal differences between different segments of the transects. The number of taxa per segment ranged between one and nine and increased towards the continental rise. This trend concurred with an increase in mean total densities (Table 4).

The taxonomic composition of eastern and western transects differed significantly (global $R=0.57 ; p<0.05$ ). While the regions "East" and "West" differed significantly in the number of taxa and their mean overall abundances, this was not true for diversity and evenness (Table 4). Results from MDS indicated that the "central" transect (PS57-106) was more similar to the westernmost transects than to the eastern parts of the study area (Fig. 5). The regions "East" and "West" were distinguished mainly by the presence or absence of B. margaritacea and A. abyssi (Table 4). Five taxa accounted for $75 \%$ of the differences between the station groups. While Amphipoda sp. was a 

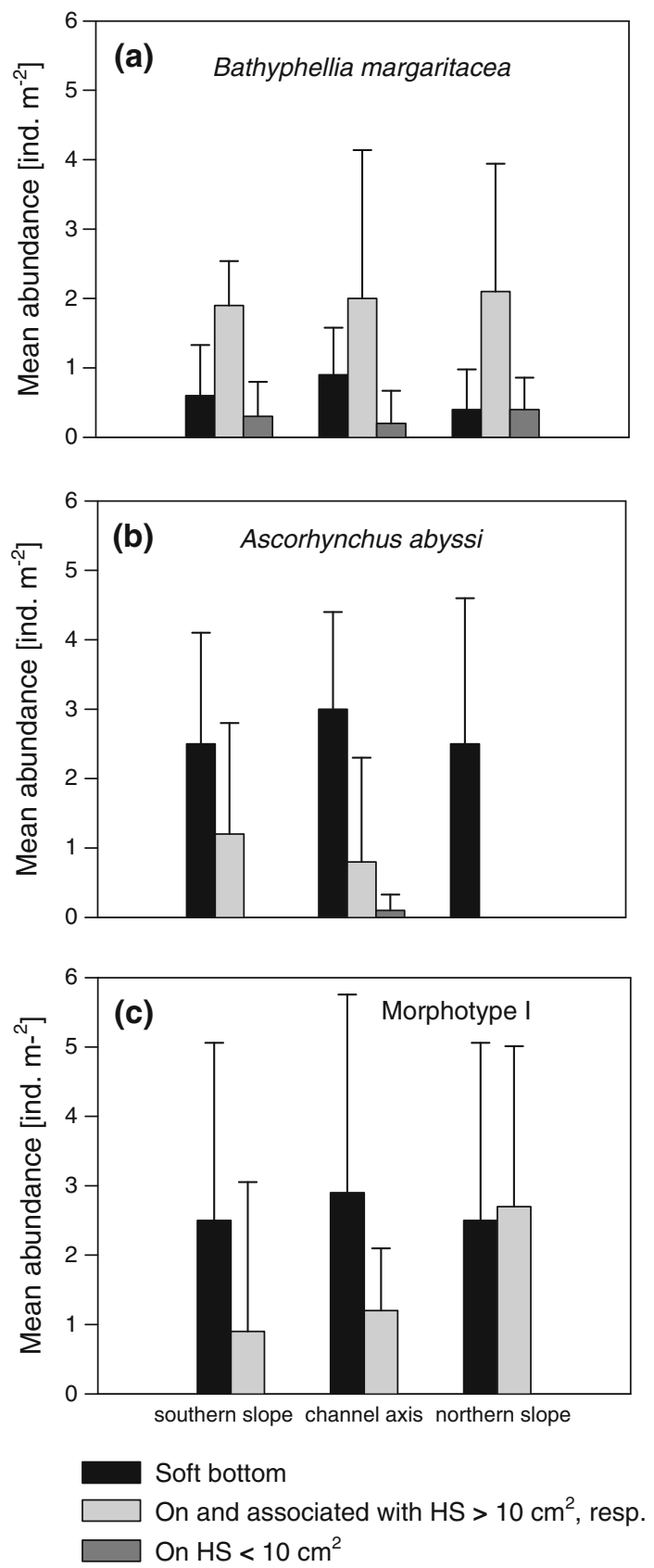

Fig. 4 Mean abundance of dominant taxa along various sections of transect PS57-89 crossing the channel profile: a Bathyphellia margaritacea; b Ascorhynchus abyssi; c Morphotype I

discriminating taxon of the region "East", Morphotype II was characteristic of the western part.

\section{Discussion}

Hard substrata as habitat islands?

The presence of dropstones can enhance epifaunal densities and diversity of the deep seafloor (Syvitski et al. 1989;
MacDonald et al. 2010), although ice-rafted debris on present-day abyssal plains is confined to environments north of $40^{\circ} \mathrm{N}$ (Kidd and Huggett 1981). In these areas, debris from melted sea ice and icebergs are available for the settlement of larvae and juveniles of benthic organisms.

Epifaunal abundance on hard substrates (this study) as well as on sponge stalks in the deep Pacific was positively correlated with substrate size (Beaulieu 2001). No such relationship was found for manganese nodules and whale bones (Mullineaux 1987; Bennett et al. 1994), where surface structure and chemistry might affect colonisation.

Seafloor imagery reveals that hard substrata can influence small-scale colonisation patterns in different ways. The surface of dropstones is subject to changes over time, which may affect the recruitment success (Mullineaux 1988). They can serve as substrate for sessile colonisers, notwithstanding a considerable variability in their occurrence, density and composition. Indeed, the dense colonisation of various dropstones indicates their role as oases for HS-limited taxa (e.g. encrusting sponge-like forms, hydrozoan colonies). On the other hand, they obviously alter the micro-environment of adjacent soft-bottom benthos, favouring aggregations of organisms associated to the structures. This is especially true for wooden debris found in the Ardencaple Canyon, which often appeared to be degraded. The majority of wooden surfaces were not colonised, but showed conspicuous aggregations of associated biota. Similarly, Bennett et al. (1994) found macroorganisms predominantly in association with organically-rich whale bones, as microbial degradation of the bone's surface may restrict an epifaunal colonisation.

Debris of anthropogenic origin appears to be widespread on continental shelves and slopes along the European coasts (Galgani et al. 2000), though information about colonisation is rare. However, Bathyphellia margaritacea was found to be attached to litter collected in the Molloy Hole (Bergmann, unpublished data). There was no evidence for macro-colonisation on beached debris observed in the Antarctic (Convey et al. 2002). Nevertheless, plastic and metallic surfaces might be covered by microbiota (Fera et al. 1987).

Colonisation patterns of hard substrata in the western Greenland Sea

Dropstones from the deep Arctic seafloor differ considerably from rocky shallow-water habitats such as boulder patches in the Beaufort Sea, where only a small proportion of the substrate surface is bare rock. They represent hardbottom oases, with the richest and most diverse biological community in the area and intense competition for space and light (Dunton et al. 1982; Dunton and Schonberg 2000; Konar and Iken 2005; MacDonald et al. 2010). 
Table 4 Structural community parameters (according to Clarke 1993) at various channel regions

\begin{tabular}{|c|c|c|c|c|c|}
\hline \multirow[t]{2}{*}{ Discriminator taxa } & \multicolumn{2}{|c|}{ Mean abundances (Ind. $\mathrm{m}^{-2}$ ) } & \multirow[t]{2}{*}{ Mean dissimilarity $\left(\delta_{\mathrm{k}}\right)$} & \multirow[t]{2}{*}{$\mathrm{SD}\left(\delta_{\mathrm{k}}\right)$} & \multirow[t]{2}{*}{$\%$} \\
\hline & East & West & & & \\
\hline B. margaritacea & 220.2 & 406.5 & 15.5 & 1.3 & 27.5 \\
\hline A. abyssi & 45.1 & 54.8 & 9.6 & 1.2 & 17.1 \\
\hline Morphotype II & 0 & 51.8 & 7.2 & 1.1 & 12.8 \\
\hline Amphipoda sp. & 48.9 & 1.5 & 6.4 & 0.7 & 11.4 \\
\hline Actinaria ?* & 6.4 & 13.7 & 3.8 & 1 & 6.8 \\
\hline
\end{tabular}

$\delta_{k}$ average dissimilarity, $S D\left(\delta_{k}\right)$ standard deviation, \% percentage contribution of each species to the discrimination of station groups
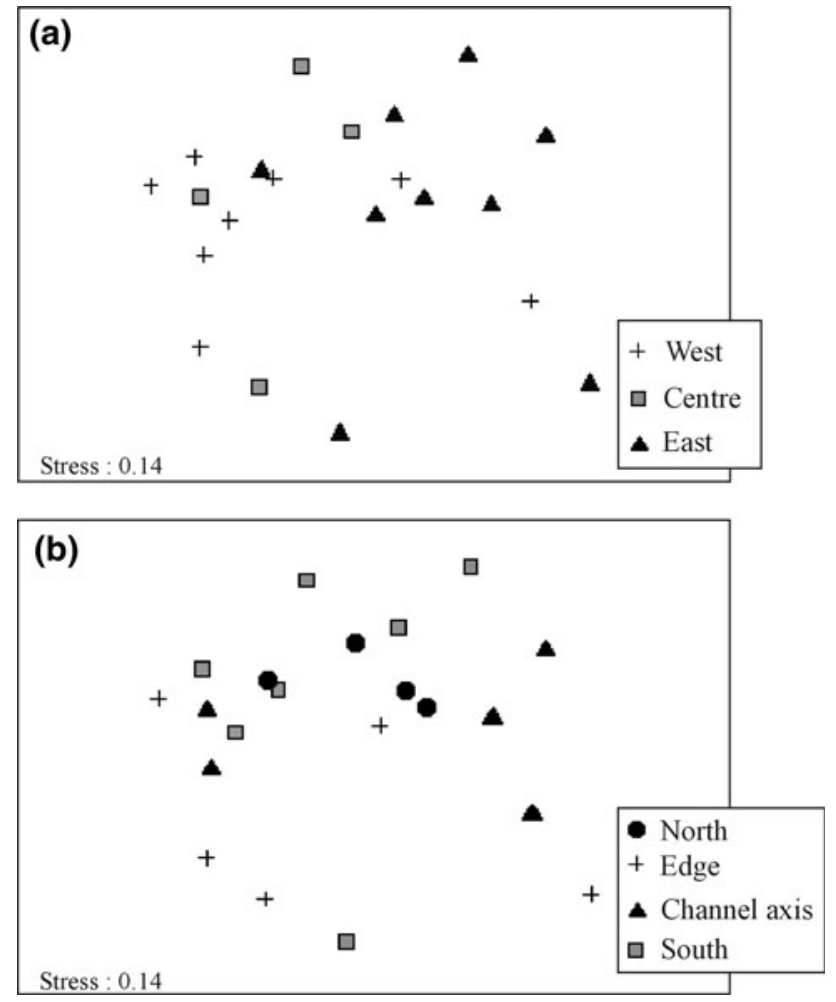

Fig. 5 MDS plot of HS-linked organisms along the Ardencaple Canyon: a Symbols reflect the relative position of transects along the channel course; b Symbols reflect relative position of single segments along the channel course

The anemone $B$. margaritacea and the pantopod Ascorhynchus abyssi dominated the fauna on hard substrata from the Ardencaple Canyon. Bathyphellia margaritacea is flexible in its choice of substrata and was also recorded from small stones, shell fragments or sea urchin tests. As with various other sea anemones, they were also reported to live loosely attached to the sediment (Riemann-Zürneck 1997), which might contribute to their wide distribution in the study area (Bergmann et al. 2009; Soltwedel et al. 2009). Sponges and bryozoans are often restricted to regions, where bottom currents provide favourable feeding conditions (Gutt and Schickan 1998; Starmans et al. 1999). Thus, an elevated position providing an enhanced horizontal particle flux could favour the survival of suspension feeders in a deep-sea "low-flow" environment, as has been shown for the colonisation of manganese nodule habitats in the northern Pacific (Mullineaux 1988). The motile pantopod, by contrast, is probably attracted to prey such as hydrozoans and other epibiota. Spatial pattern of motile fauna may reflect the distribution of their prey (Thomasson and Tunberg 2005), for instance amphipods feeding on sessile organisms on sponge stalks (Beaulieu 2001). Oschmann (1990) reported low numbers of predators on dropstones, but noted caprellid amphipods and isopods occasionally climbing on bryozoans colonies. In this study, motile fauna in the vicinity of hard substrates included the small-sized holothurian Elpidia heckeri as well as amphipods and gastropods, probably grazing on deposited organic matter.

Large rocks were rare and sparsely colonised, sometimes showing extensive accumulations of the ball-shaped Morphotype I at their periphery. This morphotype, although larger in size, resembles foraminiferal mudballs, which are common in the north Atlantic and GreenlandIceland-Norwegian Seas (Linke 1989; Gooday et al. 1997). Gooday et al. (1997) suggested that mudball-like komokiaceans might be deposit-feeders, which will profit from an enhanced deposition of organic matter caused by smallscale flow patterns surrounding large structures (Sokolova 2000). So far, it could be neither confirmed nor disproved that Morphotype I contains komokiaceans (Gooday, pers. comm.).

Influence of the channel topography on substrata availability and colonisation

The segments investigated from the Ardencaple Canyon floor and the levees showed no significant faunal differences, similar to the patterns of activity and biomass of the small benthic biota in the area. (Soltwedel et al. 2005). The southern slope terrain of the channel is relatively steep and characterised by stones and a rough topography, but most of the hard substrates were sparsely colonised (transect PS57-106). The distribution patterns of stalked crinoids 
and large anemones lead to the suggestion that such exposed habitats represent high-energy environments, which are unfavourable for larval settlement of suspension and tentacle feeders (Juterzenka and Soltwedel, unpubl. data.). On a larger scale, a trend of decreasing food availability and total microbial biomass with distance from the Greenland Sea continental margin (Soltwedel et al. 2005) concurs with a shift in epifaunal abundance and number of taxa on hard substrates from the east to the central channel. By contrast, evenness and species diversity did not differ between channel regions, resembling the macrofaunal community parameters described from the continental margin off Svalbard (Włodarska-Kowalczuk 2004). Overall, benthic community patterns seem to follow a bathymetric/shelf distance zonation at the Greenland Sea slope, which has also been described for megafauna between 190 and 2,800 $\mathrm{m}$ depth at $75^{\circ} \mathrm{N}$ (Mayer and Piepenburg 1996). A seasonally high export of organic particles in the MIZ and increased food availability may sustain high epifaunal densities at the continental rise and the western part of the Ardencaple Canyon (Ramseier et al. 1999; Peinert et al. 2001).

This study provides further evidence from Arctic Seas that the presence of dropstones and sunken wood lead to a niche versification and contribute to explain high species numbers in deep-sea environments (e.g. Grassle and Maciolek 1992). To assess the effects of small-scale environmental gradients around various substrata on the diversity of benthic organisms and the temporal succession of colonisation, experimental studies are required.

Acknowledgments This work was part of the ARKTIEF II programme funded by the German Federal Ministry for Education and Research (BMBF grant 03PL030A). We thank the crew of RV Polarstern for their support during expeditions ARK XVI/1 and ARK XVII/1. The taxonomic help of B. Bader (Bryozoa), A. Gooday (Xenophyophorida), F. Krapp, I. Suck (Pantopoda), K. RiemannZürneck (Anthozoa), A. Gebruk, M. Schmid (various megafauna), and statistical advice of D. Piepenburg is gratefully acknowledged. We are indebted to three anonymous reviewers for significant improvements to an earlier draft of the manuscript. This paper is based on Miriam Dickmann's master thesis (Universität Rostock) and is publication awi-n18586 of the Alfred Wegener Institute for Polar and Marine Research.

Open Access This article is distributed under the terms of the Creative Commons Attribution Noncommercial License which permits any noncommercial use, distribution, and reproduction in any medium, provided the original author(s) and source are credited.

\section{References}

Ambrose WG Jr, Clough LM, Tilney PR, Beer L (2001) Role of echinoderms in benthic remineralization in the Chukchi Sea. Mar Biol 139:937-949
Andersen M (1971) Echinodermata from Jørgen Brønlund Fjord, North Greenland. Meddel Grønl 184:5-18

Baco AR, Smith CR (2003) High species richness in deep-sea chemoautotrophic whale skeleton communities. Mar Ecol Prog Ser 260:109-114

Barthel D, Tendal OS (1993) The sponge association of the abyssal Norwegian-Greenland Sea: Species composition, substrate relationships and distribution. Sarsia 78:83-96

Beaulieu SE (2001) Life on glass houses: sponge stalk communities in the deep sea. Mar Biol 138:803-817

Bennett BA, Smith CR, Glaser B, Maybaum HL (1994) Faunal community structure of a chemoautotrophic assemblage on whale bones in the deep northeast Pacific Ocean. Mar Ecol Prog Ser 108:205-223

Bergmann M, Dannheim J, Bauerfeind E, Klages M (2009) Trophic relationships along a bathymetric gradient at the deep-sea observatory HAUSGARTEN. Deep Sea Res I 56:408-424

Bluhm H (1994) Monitoring megabenthic communities in abyssal manganese nodule sites of the East Pacific Ocean in association with commercial deep-sea mining. Aquat Conserv Mar Freshwat Ecosyst 4:187-201

Bluhm BA, MacDonald IR, Debenham C, Iken K (2005) Macro- and megabenthic communities in the high Arctic Canada Basin: initial findings. Polar Biol 28:218-231

Bray JR, Curtis JT (1957) An ordination of the upland forest of southern Wisconsin. Ecol Monogr 27:225-349

Buhl-Mortensen L, Vanreusel A, Gooday AJ, Levin LA, Priede IG, Buhl-Mortensen P, Gheerardyn H, King NJ, Raes M (2010) Biological structures as a source of habitat heterogeneity and biodiversity on the deep ocean margins. Mar Ecol 31:21-50

Christiansen B, Thiel H (1992) Deep-sea epibenthic megafauna of the northeast Atlantic: abundance and biomass at three mid-oceanic locations estimated from photographic transects. In: Rowe GT, Pariente V (eds) Deep-sea food chains and the global carbon cycle. Kluwer, Netherlands, pp 125-138

Clarke KR (1993) Non-parametric multivariate analyses of changes in community structure. Austr J Ecol 18:117-143

Clarke KR, Warwick RM (1994) Changes in marine communities: an approach to statistical analysis and interpretation. Natural Environment Research Council, Plymouth Marine Laboratory

Convey P, Barnes DKA, Morton A (2002) Debris accumulation on oceanic island shores of the Scotia Arc, Antarctica. Polar Biol 25:612-617

Dunton HD, Schonberg S (2000) The benthic faunal assemblage of the Boulder Patch kelp community. In: Truett JC, Johnson SR (eds) The natural history of an Arctic oil field: development and the biota. Academic Press, San Diego, pp 371-397

Dunton HD, Reimnitz E, Schonberg S (1982) An Arctic kelp community in the Alaskan Beaufort Sea. Arctic 35:465-484

Fahrbach E et al (2002) The expedition ARKTIS XVII/1 of the research vessel POLARSTERN in 2001. Rep Polar Mar Res 433:1-60

Felley JD, Vecchione M, Wilson RR Jr (2008) Small-scale distribution of deep-sea demersal nekton and other megafauna in the Charlie-Gibbs Fracture Zone of the Mid-Atlantic Ridge. Deep Sea Res II 55:153-160

Fera P, Prieur D, Antoine E (1987) Experimental study on the bacterial colonization of metallic and plastic surfaces, immersed in sea water. Mar Life $8: 1-8$

Field JG, Clarke KR, Warwick RM (1982) A practical strategy for analysing multispecies distribution patterns. Mar Ecol Prog Ser $8: 37-52$

Gaevskaja NS (1948) Bestimmungsbuch der Fauna und Flora der nördlichen Meere der UdSSR, Moscow

Galgani F, Leaute JP, Moguedet P, Souplets A, Verin Y, Carpentier A, Goraguer H, Latrouite D, Andral B, Cadiou Y, Mahe JC, 
Poulard JC, Nerisson P (2000) Litter on the sea floor along European coasts. Mar Poll Bull 40:516-527

Gooday A, Shires R, Jones AR (1997) Large, deep-sea agglutinated foraminifera: two differing kinds of organization and their possible ecological significance. J Foraminifer Res 27:278-291

Grassle JF, Maciolek NJ (1992) Deep-sea species richness: regional and local diversity estimates from quantitative bottom samples. Am Nat 139:313-341

Gutt J, Schickan T (1998) Epibiotic relationship in the Antarctic benthos. Antarct Sci 10:398-405

Kidd RB, Huggett QJ (1981) Rock debris on abyssal plains in the Northeast Atlantic: a comparison of epibenthic sledge hauls and photographic surveys. Oceanol Acta 4:99-104

Konar B, Iken K (2005) Competitive dominance among sessile marine organisms in a high Arctic boulder community. Polar Biol 29:61-64

Krause G, Schauer U (2000) The expeditions ARKTIS XVI/1 and ARKTIS XVI/2 of the research vessel "Polarstern" in 2000. Rep Polar Res 389

Kruskal JB (1977) Multidimensional scaling and other methods for discovering structure. In: Enslein K, Ralston A, Wilf HS (eds) Statistical methods for digital computers. Wiley, New York, pp 296-339

Linke P (1989) Lebendbeobachtungen und Untersuchngen des Energiestoffwechsels benthischer Foraminiferen aus dem Europäischen Nordmeer. Ber SFB 313. Christian-Albrechts-Universität zu Kiel 18:1-123

MacDonald IR, Bluhm BA, Iken K, Gagaev S, Strong S (2010) Benthic macrofauna and megafauna assemblages in the Arctic deep-sea Canada Basin. Deep Sea Res II 57:136-152

Mayer M, Piepenburg D (1996) Epibenthic community patterns on the continental slope off East Greenland at $75^{\circ} \mathrm{N}$. Mar Ecol Prog Ser 143:151-164

Mullineaux LS (1987) Organisms living on manganese nodules and crusts: distribution and abundance at three North Pacific sites. Deep Sea Res I 34:165-184

Mullineaux LS (1988) The role of settlement in structuring a hardsubstratum community in the deep sea. Mar Biol Ecol 120:247261

Oschmann W (1990) Dropstones—rocky mini-islands in high-latitude pelagic soft substrate environments. Senkenbergiana Marit 21:55-75

Peinert R, Bauerfeind E, Gradinger R, Haupt O, Krumbholz M, Peeken I, Werner I, Zeitzschel B (2001) Biogenic particle sources and vertical flux patterns in the seasonally ice-covered Greenland Sea. In: Schäfer P, Ritzrau W, Schlüter M, Thiede J (eds) The northern North Atlantic: a changing environment. Springer, Berlin, pp 69-79

Pielou EC (1977) Mathematical ecology. Wiley, New York

Ramseier RO, Garrity C, Bauerfeind E, Peinert R (1999) Sea-ice impact on long term particle flux in the Greenland Sea's Is Odden-Nordbukta region during 1985-1996. J Geophys Res 104:5329-5343

Ramseier RO, Garrity C, Martin T (2001) An overview of sea-ice conditions in the Greenland Sea and the relationship of oceanic sedimentation to the ice regime. In: Schäfer P, Ritzrau W, Schlüter M, Thiede J (eds) The northern North Atlantic: a changing environment. Springer, Berlin, pp 19-38

Rice AL, Aldred RG, Darlington E, Wild RA (1982) The quantitative estimation of the deep-sea megabenthos; a new approach to an old problem. Oceanol Acta 5:63-72

Riemann-Zürneck K (1997) The deep-sea anemones Bathyphellia margaritacea and Daontesia porcupina sp. nov. with comments on the family Bathyphelliidae. J Mar Biol Ass UK 77:361-374

Schuchert P (2001) Hydroids of Greenland and Iceland (Cnidaria, Hydrozoa). Meddel Grönl Biosci 53:1-18

Shannon CE, Weaver W (1949) The mathematical theory of communication. University of Illinois Press, Urbana

Sokolova MN (2000) Feeding and trophic structure of the deep-sea macrobenthos. Science Publishers, Enfield

Solan M, Germano JD, Rhoads DC, Smith C, Michaud E, Parry D, Wenzhöfer F, Kennedy B, Henriques C, Battle E, Carey D, Iocco L, Valente R, Watson J, Rosenberg R (2003) Towards a greater understanding of pattern, scale and process in marine benthic systems: a picture is worth a thousand worms. J Exp Mar Biol Ecol 285-286:313-338

Soltwedel T, Hasemann C, Quéric N-V, v Juterzenka K (2005) Gradients in activity and biomass of the small benthic biota along a channel system in the deep Western Greenland Sea. Deep Sea Res I 52:815-835

Soltwedel T, Jaeckisch N, Ritter N, Hasemann C, Bergmann M, Klages M (2009) Bathymetric patterns of megafaunal assemblages from the arctic deep-sea observatory HAUSGARTEN. Deep Sea Res I 56:1856-1872

Starmans A, Gutt J, Arntz WE (1999) Mega-epibenthic communities in Arctic and Antarctic shelf areas. Mar Biol 135:269-280

Stephensen K (1943) The zoology of east Greenland: Leptostraca, Mysidacea, Cumacea, Tanaidacea, Isopoda and Euphausiacea. Meddel Grønl 121:82

Stephensen K (1944) The zoology of east Greenland: Amphipoda. Meddel Grønl 121:165

Syvitski JPM, Farrow GE, Atkinson RJA, Moore PG, Andrews JT (1989) Baffin Island Fjord macrobentos: bottom communities and environmental significance. Arctic 42:232-247

Thomasson MA, Tunberg BG (2005) Composition and vertical distribution of the motile epifauna on a vertical wall in Gullmarsfjorden, western Sweden, using an alternative sampling approach. Mar Biol Res 1:107-117

Vinje TE (1977) Sea ice conditions in the European sector of the marginal seas of the Arctic, 1966-1975. Norsk Polarinst Årbok 1975:163-174

Witte U (1995) Reproduktion, Energiestoffwechsel und Biodepositionsleistung dominanter Porifera aus der Tiefsee des Europäischen Nordmeeres. Ber SFB 313, Christian-Albrechts-Universität zu Kiel, 53 p

Włodarska-Kowalczuk M (2004) Depth gradients of benthic standing stock and diversity on the continental margin at a high-latitude ice free site (of Spitsbergen, $79^{\circ} \mathrm{N}$ ). Deep Sea Res I 51:19031914 